示した值は RCL 社製 256 チャネル波高分析器により クトルを求めた場合に 20count/min/channel のピークを示す に必要な ppm 值であり,これを定量限界値と考えた。

\section{3 他の分析法による結果との比較}

著者らの分析した試料と同一の試料について，日本鉱業日立鉱 業所分析課において分析していただいた定量值を比較のため，表 2,3 に記した*2。定量限界以下の值が多いため明確に断言しえ ないが、ほほ一致した值を示している。

\section{4 考 察}

現在使用できる JRR-1 の中性子を用いての放射化分析ではな お感度不十分である。試料が高純度になればなるほど定量できる 不純物の数ががられることは当然である。これは一つには中性

\footnotetext{
*2 私信による，金中の銅はネオクプロインによろ比色，パラジムは 1,2-ピ リシルーアソー2-ナフトールによる比色，七素，アンチモンは分光分析により 定量. 銀中の銅はネオクプロイン, 金は酶酸アミル，ヒ素はモリブデン酸ア ンモニウム、アンチモンはヨウ化カリウムによる比色分析により定叟.
}

子束が低いことに基づくし，いま一つは金，銀のような中性子吸 収断面積の大きい試料では，中性子シャヘイの見地から使用しう る試料の量が限定されることに起因している。JRR-2 の利用が できるようになれば中性子束が現在の約 200 倍に増加するので感 度の不十分さが相当おぎなえるものと期待される。

中性子シャヘイの点から試料の量ががきられることは，放射化 分析の欠点の一つであるかも知れないが，逆にいえば中性子束が 大になり感度が十分になれば，高価な試料も少量ですむこと，大 きな試料母体中の不純物の偏在を知るに最適であること（銅中の 不純物の放射化分析において報告した）など放射化分析の特徴で もある。

試料について御心配いただいた日本鉱業日立鉱業所分析課の方 々，とくに研究の一部を担当していただいた同所の中村 靖，桜 井英夫の両氏に感謝する。

\title{
金属トリゥムおよび酸化トリゥム中の希土類元素の放射化分析
}

(昭和 35 年 8 月 3 日受理)

中井 敏夫†·矢島 聖使†・藤 井 勲†† ·亀本雄一郎†・柴 是 行†

高純度トリウム中に含まれる微量の希土類元素を定量するととは従来の分析法ではいろいろと難かしい点を持っていた。本報で は中性子放射化分析をるちいて比較的简単に定量する方法を提出した。

すなわち，金属状トリウムまたは酸化トリウム約 $100 \mathrm{mg}$ をランタン，サマリウム，ユーロピウム，シスプロシウムの各標準と 並べて JRR-1 中で中性子照射を扣てなった。放射化された試料から，ランタンを担体として水酸化物の沈殿，イオン交換樹脂に よるプロトアクチニウムの分雄除去，シュウ酸㙁の沈殿などの化学処理により，希土類元素のみを純にとり出した。との放射能を

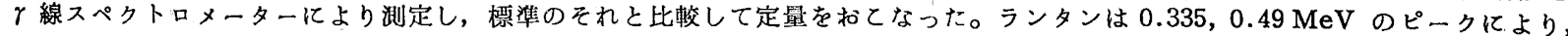
サマリウム, ユーロピウム, シスプロシウムは約 $40 \mathrm{keV}$ のピークの敖変曲線を解析するととにより定量した。とのう法により， ランタン 60〜3000 ppm，サマリウム 3〜100 ppm，ユーロピウム 0.05〜20 ppm，シスプロシウム0.09〜900 ppmの䈨度筙囲の 定量を扣てなうととができた。

\section{1 緒官}

トリウムを核燃料として使用する場合には，希土類元絜が非常 に大きい熱妕性子吸収断面樍 (thermal neutron absorption cross-section) をもつため, その微量の存在が問題となる。諸外 国の核燃料用酸化卜リウムの仕様を見ても，希土類元素のうちで もとくに熱中性子吸収断面積の大きいガドリニウム, サマリウム， ユーロピウム, ジスプロシウムなどはいずれもその含量を $1 \mathrm{ppm}$

\footnotetext{
†日本原子力研究所, 炎城県那珂都東海村
}

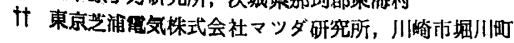

以下に規定されている。したがってトリウム中に含まれるこのよ うに微量の個々の希土類元装の定量法の確立が強く要望されてお り, 分光分析法を始め, 数多くの微量分析法の研究がなされてき た1)が，いずれの方法むそれぞれ未解決の問題点を含んでいる。 幸にこれらの希土類元素はいずれも大きい放射化断面積を持って おり，放射化分析によりきわめて感度よく定量しうるので，この 微量分析法をトリウム試料の分析に適用する研究を進めた。

1) たとえば, L. Gordon, F. H.Firsching, K. J. Shaver, Anal. Chem. 28, 1476 (1956); M. W. Lerner, G. J. Petretic, ibid. 28, 227 (1956); C. Feldman, J. Y. Ellenburg, ibid. 30, 418 (1958); L. W. Wray, CRDC-742, AECL-546 (1957). 


\begin{tabular}{|c|c|c|c|c|c|}
\hline $\begin{array}{l}\text { 放射化さ } \\
\text { れる核種 }\end{array}$ & $\begin{array}{c}\text { 存在比 } \\
(\%)\end{array}$ & $\begin{array}{l}\text { 生 成 } \\
\text { 核 種 }\end{array}$ & $\begin{array}{l}\text { 表 } 1 \\
\text { 半娍期 }\end{array}$ & $\begin{array}{l}\text { 希 土類 元 素の核 特 性 }{ }^{3)} \\
\text { 睡変型扣よびエネルギー }(\mathrm{MeV})\end{array}$ & $\begin{array}{c}\text { 放射化断面積 } \\
\text { (barn) }\end{array}$ \\
\hline${ }^{189} \mathrm{La}$ & 99.911 & ${ }^{140} \mathrm{La}$ & $40.2 \mathrm{~h}$ & $\beta^{-} 1.34$ その他, $\gamma 0.3286,0.4867,0.8151,1.596$ & 8.4 \\
\hline${ }^{152} \mathrm{Sm}$ & 26.63 & ${ }^{153} \mathrm{Sm}$ & $47 \mathrm{~h}$ & $\beta-0.645,0.720,0.825, \gamma 0.103,0.070$ & 150 \\
\hline${ }^{151} \mathrm{Eu}$ & 47.77 & ${ }^{152} \mathrm{Eu}$ & $9.2 \mathrm{~h}$ & $\beta^{-} 1.88, \mathrm{~K}, \gamma 0.122,0.344$ & 1400 \\
\hline${ }^{164} \mathrm{Dy}$ & 28.18 & ${ }^{165} \mathrm{Dy}$ & $2.32 \mathrm{~h}$ & $\beta^{-} 1.25,0.88,0.3, \gamma 0.0944,0.27,0.36$ & $<1000$ \\
\hline
\end{tabular}

放射化分析による希土類元素の定量については，すでにいくつ かの報告が見られる2。。しかしこれらの方法をそのままトリウム 試料の分析に適用することはできないので, 著者らは分析法をさ らに検討し, 比較的簡単な化学分離法と $\gamma$ 線スペクトロメトリー を主体とする放射化分析を試み，ほぼ満足すべき結果を得たので その結果を報告する。

\section{2 実験}

\section{1 各希土類元素の核特性および中性子照射}

JRR-1 を中性子源として用いた場合には，希土類元素の中で 放射化分析で高感度で定量できるものは, 存在量, 放射化断面積, 生ずる核種の半減期から, ランタン, サマリウム, ユーロピウム, シシスプロシウムの 4 元素である。これら四つの核種の核特性を表 1 亿示す。表中の半減期からわかるように, ランタン, サマリウ ムに対しては長時間の中性子照射が有利であり, ユ一ロピウム, ジスプロシウムに対しては短時間の照射が有利である。

したがって著者らは現在使用しうる照射条件の中で 3 日間 (1 日最大 5 時間) の中性子照射をおこなった試料から，主としてラ ンタン,サマリウムを定量し, 2 時間中性子照射をおこなった試料 から主としてユーロピウム, シスプロシウムの定量をおこなった。 中性子照射はすべて JRR-1 原子炉中でおこなった。試料および 標準試料をならべて同一のキャプセルに入れ，長時間照射の場合 は No. 6 実験孔，短時間照射の場合は No. 16 (気送管) 実験 孔で中性子照射をおこなった。中性子束はいずれの場合も約 $3 \times$ $10^{11} \mathrm{n} / \mathrm{cm}^{2} / \mathrm{sec}$ であった。

\section{2 試料および標準試料}

金属トリウムは東北大学金属材料研究听竹内研究室におい て 溶融塩電解, カルシウム還元などにより精製された試料であ る。

酸化トリウムは金属トリウム製造の原料，Lindsay 社製の標 準試料，およびわが国の $\mathrm{A}$ 社， M 社製核然料用高純度酸化トリ ウムを試料とした。

䅺準試料はランタン, サマリウム, ユーロピウムおよびジスプ ロシウムの酸化物*1 を硝酸にとかし，適当にうすめてそれぞれ $102.44,18.282,0.6339$ および $1.368 \mu \mathrm{g} / \mathrm{ml}$ の溶液をつくっ た。この溶液 $0.1 \mathrm{~m} l$ を径 $2 \mathrm{~cm}$ の口紙 2 枚にしみこませ, ポリ エチレン製の袋に封入して標準試料とした。照射後口紙ごとに測 定用棒状ビンに洗い込み $\gamma$ 線スペクトルを測定した。

2) W. A. Brooksbank, G. W. Leddicotte, J. Phys. Chem. 57, 819 (1953), J. V. Jakovlev, International Conference on Peaceful Uses of Atomic Energy, Geneva, P/632 (USSR) (1955); H. W. Kohn, E. R. Tompkins, ORNL-390 (1949); 浜口, 川禹，大沢，望 月, 日本化学会第 12 年会諈演 (1959年 4 月).

3) D. Strominger, J. M. Hollander, G. T. Seaborg, Rev. Modern Phys. 30, No. 2, Part 2 (1958); 浜口, 亘目, “実驗化学䍀座” 13, 「卜 レーサー技術」p. 429 (1957) 丸㖾.

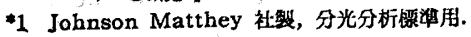

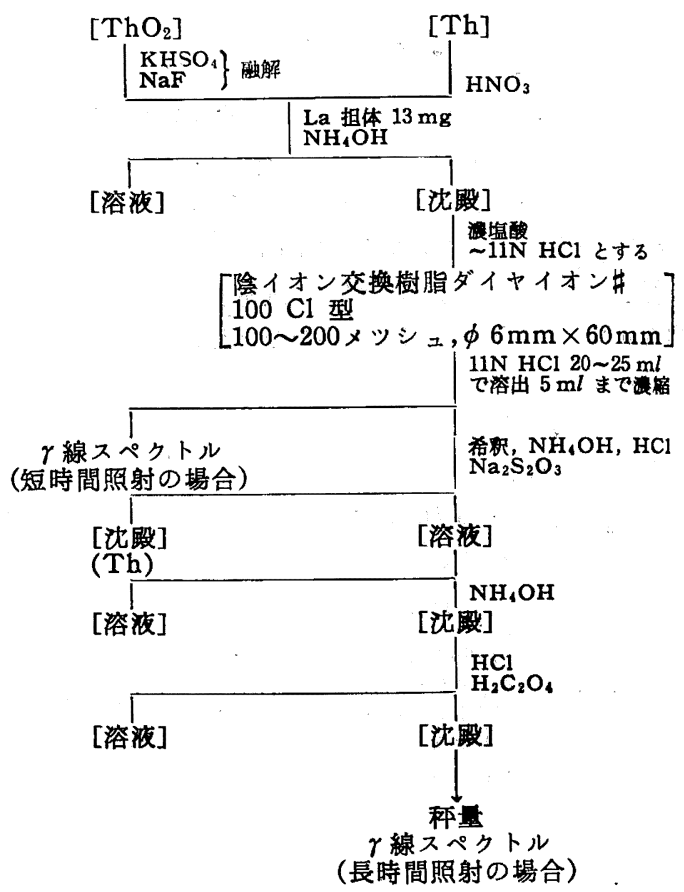

図 1 化学分晟法

\section{3 分離法}

中性子照射した試料を 2 〜 時間放置して，中性子照射により 生じた ${ }^{233} \mathrm{Th}$ を ${ }^{233} \mathrm{~Pa}$ に壊变させたのち, 図 1 に示す分㜠操作 により希土類元素を精製する。すなわち短時間中性子照射をおこ なった試料については，イオン交換樹脂法によりプロトアクチニ ウムを除去4し，浱縮して $\gamma$ 線スペクトルを測定する。長時間中 性子照射をおこなった試料についてはさらにつぎのような除染操 作をおこなう。チオ硫酸ナトリウム法によるトリウムの沈殿分 離(5)，シュウ酸による希土類元絜の沈殿》)の操作をおこない，希

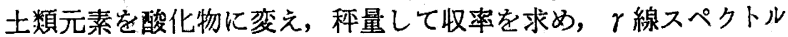
を測定する。

$\gamma$ 線スペクトルはすベて RCL-256 チャネル波高分析器 $(\mathrm{NaI}$ （T1）クリスタル $13 / 4$ インチ $\times 2$ インチ井戸型）を用いて測定 した。

\section{4 核種の同定}

前述のように放射能はすべて $\gamma$ 線シンチレーションスペクトロ メーターにより測定した。

その典型的な試料のスペクトルおよび各標準のスペクトルを図 2 〜 6 示す。ランタンは $0.335,0.49 \mathrm{MeV}$ に特有のスペクト ルが現われる。この各ピークのエネルギーと半減期からランタン

4) K. A. Kraus, F. Nelson, International Confernce on Peaceful Uses of Atomic Energy, Geneva, p/113 (1955).

5) W. W. Scott, "Standard Methods of Chemical Analysis" 5th. ed., Vol. 1, p. 249 (1954) D. Van Nostrand Co., Inc., New York. 


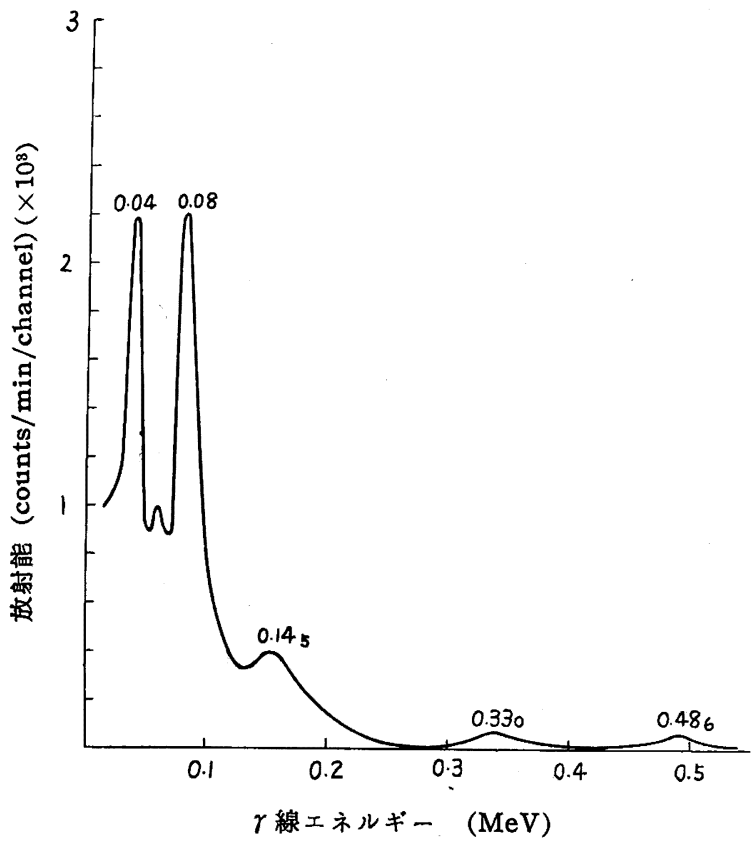

因 2 分離した希土類元素の $\gamma$ 線スペクトル

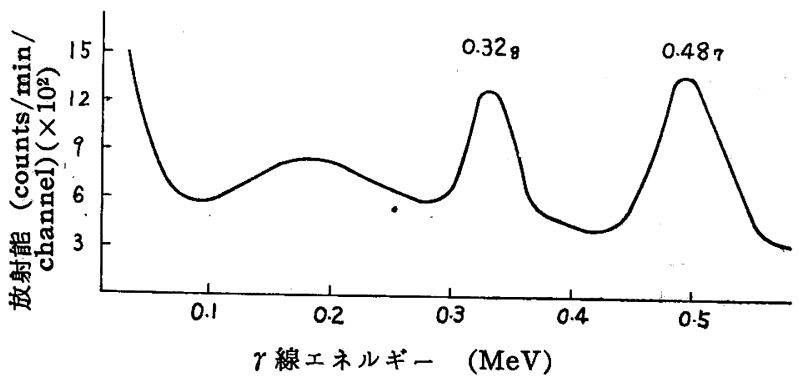

因 3 ランタンの $\gamma$ 線スペクトル

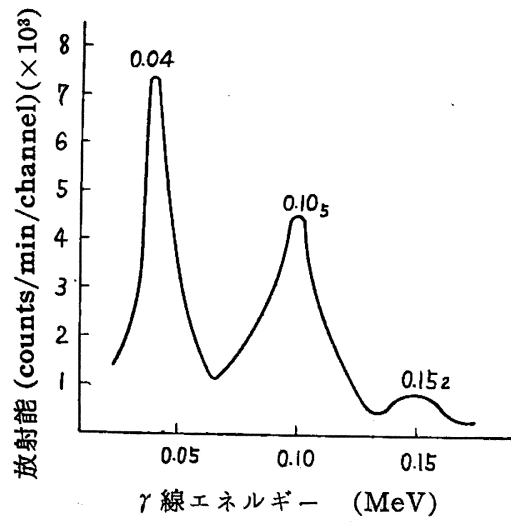

図 4 サマリウムの $\gamma$ 線スペクトル

であることを確認し, 試料の放射能を標準のそれと比較して定量 する。サマリウム, ユーロピウム, ジスプロシウムの各ピークは いくらかずつ重なって現われるため，ただちに放射能を比較する ことはできない。約 $40 \mathrm{keV}$ にこの 3 元素とむにいちじるしい ピークを示すので, 試料のこのピークの減衰をこまかく追跡し, その塆変曲線を分析して 3 元素それぞれの放射能の強さを求め, 各標準と比較して定量した。この懐変曲線の 1 例を図 7 に示 す。

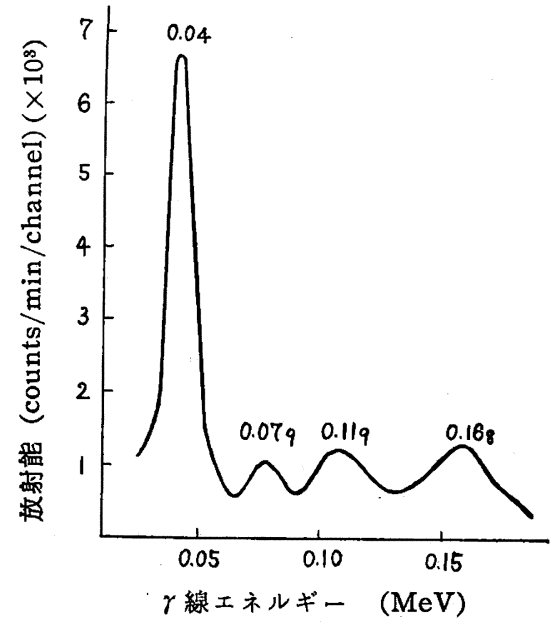

図 5 ユーロピウムの $\gamma$ 線スペクトル

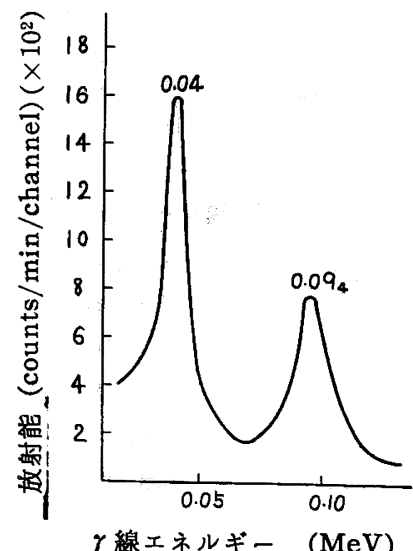

因 6 シスプロシウムの

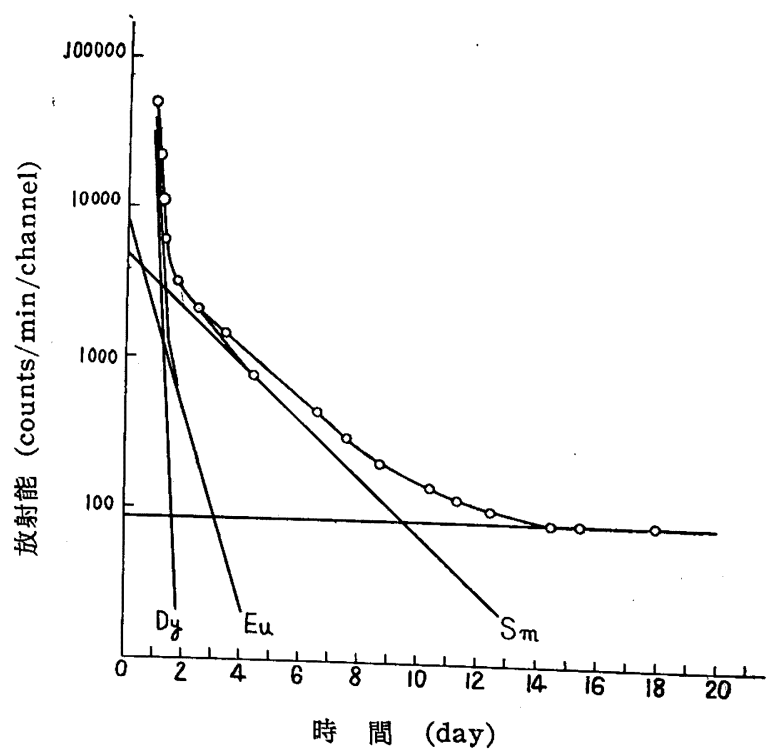

図 7 約 $40 \mathrm{keV}$ のピークの壊変曲線

\section{3 実験結果ならびに考察}

\section{1 実駼結果}

金属トリウムおよびその製造原料の酸化トリウムについての定 量値を表 2 (次頁) に，また酸化トリウムについての定量值を表 
表 2 金属トリウム中の希土類元素の定量結果

$\begin{array}{cc}\text { 試料番号 } & \text { 試 料 } \\ & \text { ThO }_{2}-76 \\ 1 & \text { (製造原料酸化トリウム } \\ 2 & \text { DFE-26 } \\ 3 & \text { ER-10 } \\ 4 & \text { ER II }-3 \\ 5 & \text { ERK-5 } \\ 6 & \text { ERK-6 } \\ 7 & \text { ERK-7 } \\ 8 & \text { EL-11 } \\ 9 & \text { CaR-1 }\end{array}$

$\begin{array}{cc} & \text { 定 } \\ \mathrm{La} & \mathrm{Sm} \\ 3000 & 400 \\ <20 & 27,26, \quad 30,27 \\ <20 & 10,8,14 \\ <20 & 2,5,2,4 \\ <20 & 5 \\ <20 & 4,7 \\ <20 & 6,8 \\ <20 & 6,6 \\ <20 & 100\end{array}$

量 值 $(\mathrm{ppm})$

表 3 酸化トリウム中の希土類元素の定量結果

\begin{tabular}{|c|c|c|}
\hline $\begin{array}{l}\text { 試 } \\
\text { 料 } \\
\text { 番 } \\
\text { 䎹 }\end{array}$ & ! 試 & 料 \\
\hline 10 & Lindsay & Code \\
\hline 11 & $M$ 社製 & $\mathrm{H}-17$ \\
\hline
\end{tabular}

3 汇まとめて示す。

表中で $<n$ で示した数值は $\gamma$ 線スペクトルにあらわれなかっ た核種であって，つぎのような仮定のもとに計算した検出限界值 である。すなわち著者らが壊変曲線を求めた条件 $(L . T .=100$ sec, $R=4095, G=5)$ に換算して,ピークの高さが $0.5 \mathrm{~cm}$ を示 すべき核種の存在量を検出限界とした。このピークの高さは，著 者らが用いた RCL-256チャネル・パルスハイト・アナライザーに おいては，約 100 counts/min/channel に相当する。

\section{2 考 察}

試料番号 $1\left(\mathrm{ThO}_{2}\right)$ について試料の量を変えて希土類元素を定 量してみたところ $100 \mathrm{mg}$ 程度までは，定量值にさして変化な
定量 值 (ppm)

$1,0.9,2 \quad 65,75$

$0.2,0.2,0.3,0.3 \quad 20,14$

$0.03,0.04,0.09,0.09$ 0.3

$0.1,0.5$

$0.1,0.5$

0.1

20

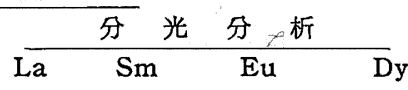

$0.06,0.05$

0.09

- 1

0.02

0.4

$0.06, \quad 0.05$

0.3

く，したがって著者らが定量に際してとった 試料の量（約 100 mg）では中性子シャヘイは起っていないと考元られる。

酸化トリウムの試料のうち Lindsay 社製の試料については分 光分析による分析值が示されているので比較のために表 3 に記し た。

興味ある一つの点は酸化トリウムにはランタンが定量され，金 属トリウムには検出されないことである。このことは酸化トリウ ムから金属トリウムを精製する際にランタンがよく除去されるこ とを示していると考えられる。

(1958 年 4 月, 第 2 回放射化学討論会, 1959 年 11 月，第 3 回放射化学討論会講演)

\section{ペーパークロマトグラフィーの研 究（第 5 報） \\ 無機物の水溶液を展開剤としたマンガン, コバルト,ニッケル，亜鉛の分離}

(昭和 35 年 8 月 3 日受理)

$$
\text { 今 井弘 }
$$

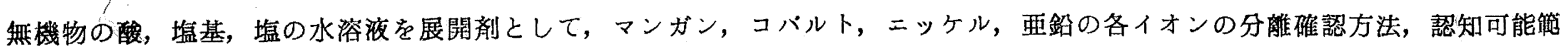

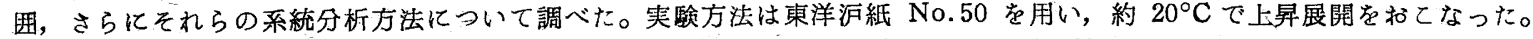

その結果，酸，塩基，塩の水溶液による展開だけでは分離するてとができないてとがわかったから，つぎの方法を工夫した。試

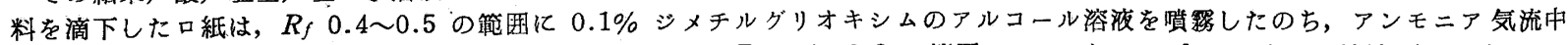

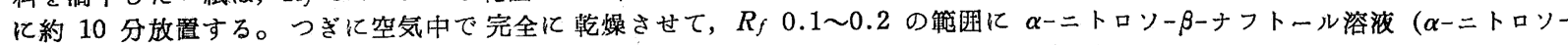

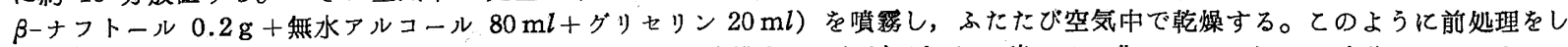
たのちに，0.5〜 4N 塩化アンモニウム溶液で展開すると分離するととができる。硫シアン化アンモニウム，硫酸アンモニウム， 硝酸アンモニウムのいずれの溶液を用いてる良く分晟するてとがでさる。との場合，マンガンはカッ色のスポットとして原点にと まり, コバルトは $\alpha-$ ニロソー $\beta$-ナフトールと反応して赤カッ色となり,ニッケルはシメチルグリオキシムと反応して紅色のスポ ットとして確認される。亜鉛は $R_{f} 0.55 \sim 1.0$ にわたる籁囲に $1 \%$ の 8-オキシキノリンのアルコール溶液を噴羁したのち，紫 外線を照射すると， $R_{f} 0.6 \sim 0.98$ 亿黄色の螢光学発する。すなわち，4 金属を完全に分晟碓虫するととができる。

\section{1 緒 論}

前報1)で鉄, アルミニウム, クロムの水酸化ナトリウム溶液に
よる分離について報告した。本報ではマンガン, コバルト, ニッ

†関西大学工学部, 大阪市大腚区

1) 今井, 日化 80, 1439 (1959). 